Prepared in cooperation with the New York City Department of Environmental Protection

\title{
Slug-Test Analysis of Selected Wells at an Earthen Dam Site in Southern Westchester County, New York
}

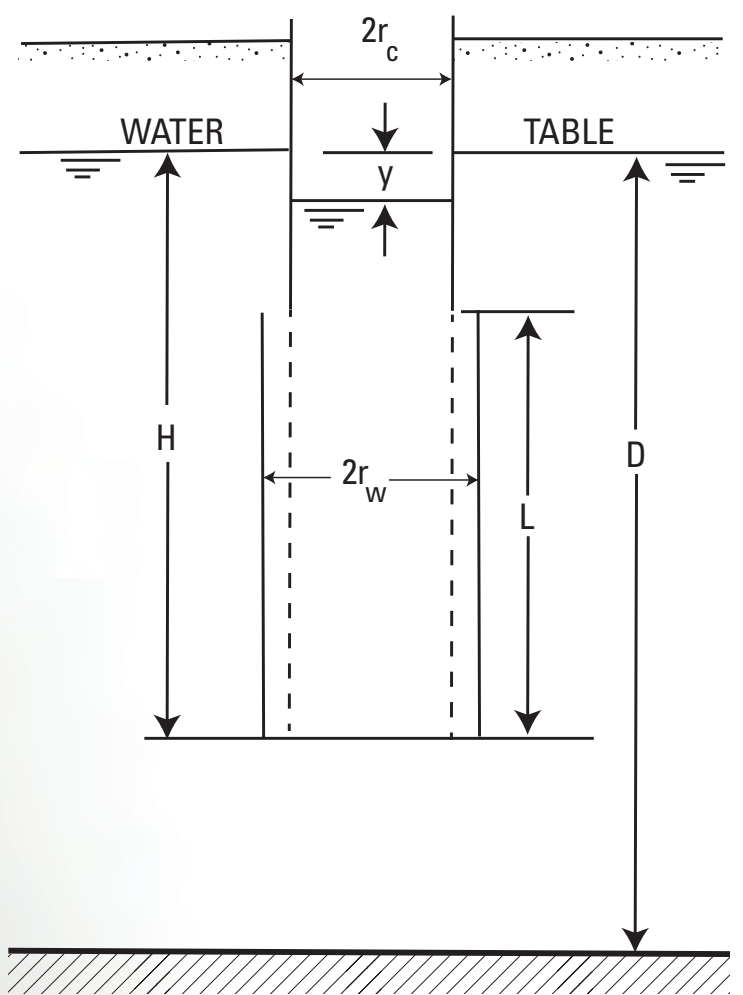

IMPERMEABLE

Open-File Report 2019-1102

U.S. Department of the Interior U.S. Geological Survey

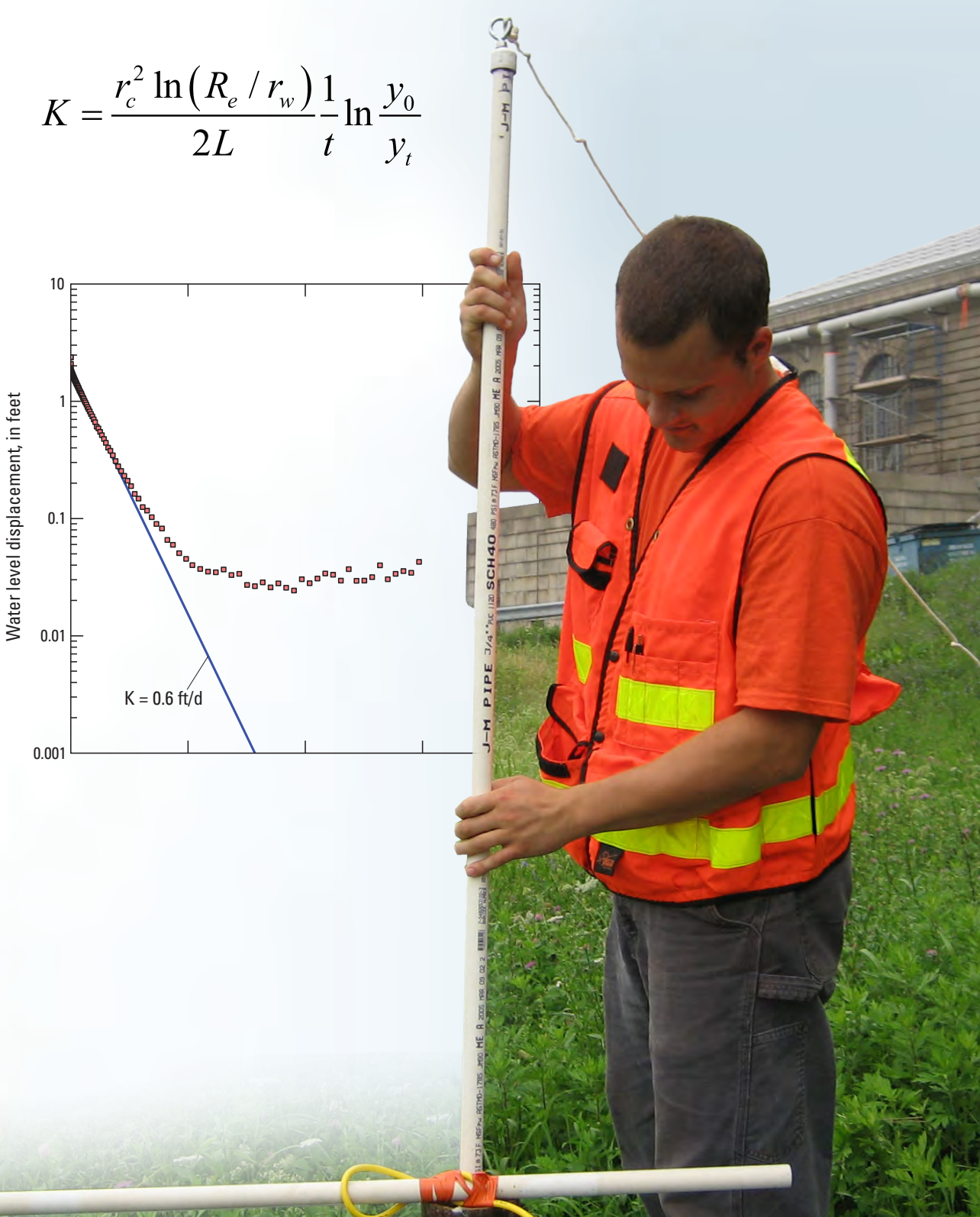

2 s k 


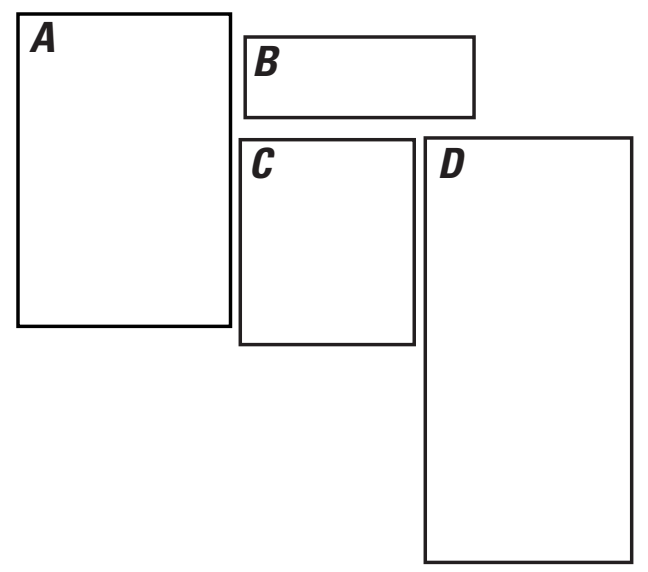

Cover. $A$, Geometry of a partially penetrating, partially perforated well in unconfined aquifer with gravel pack or developed zone around perforated section; from Bouwer and Rice (1976). B, Equation for hydraulic conductivity; from Bouwer and Rice (1976).

$C$, Straight-line plots of a slug-out test at well MB-4W at the Hillview Reservoir, Westchester County, New York. D, U.S. Geological Survey (USGS) scientist deploying a slug for a single-well aquifer test in Westchester County, New York; photograph by the USGS. 


\section{Slug-Test Analysis of Selected Wells at an Earthen Dam Site in Southern Westchester County, New York}

By Michael L. Noll, Anthony Chu, and William D. Capurso

Prepared in cooperation with the

New York City Department of Environmental Protection

Open-File Report 2019-1102 


\title{
U.S. Department of the Interior DAVID BERNHARDT, Secretary
}

\author{
U.S. Geological Survey \\ James F. Reilly II, Director
}

\section{U.S. Geological Survey, Reston, Virginia: 2019}

For more information on the USGS - the Federal source for science about the Earth, its natural and living resources, natural hazards, and the environment—visit https://www.usgs.gov or call 1-888-ASK-USGS.

For an overview of USGS information products, including maps, imagery, and publications, visit https://store.usgs.gov.

Any use of trade, firm, or product names is for descriptive purposes only and does not imply endorsement by the U.S. Government.

Although this information product, for the most part, is in the public domain, it also may contain copyrighted materials as noted in the text. Permission to reproduce copyrighted items must be secured from the copyright owner.

\section{Suggested citation:}

Noll, M.L., Chu, A., and Capurso, W.D., 2019, Slug-test analysis of selected wells at an earthen dam site in southern Westchester County, New York: U.S. Geological Survey Open-File Report 2019-1102, 14 p., https://doi.org/10.3133/ofr20191102.

Associated data for this publication:

Capurso, W.D, Chu, J.J., Chu, S.A., and Noll, M.L., 2019, Data and analytical type-curve match for selected hydraulic test in New York State: U.S. Geological Survey data release, https://doi.org/10.5066/P9J404KW.

ISSN 2331-1258 (online) 


\section{Acknowledgments}

The authors thank Richard Zunino and Will Melendez of the New York City Department of

Environmental Protection for their technical assistance and logistical support. The authors also

thank Peter Joesten and Michael D. Como of the U.S. Geological Survey for their technical

support during the slug tests. 



\section{Contents}

Acknowledgments ……...................................................................................................................

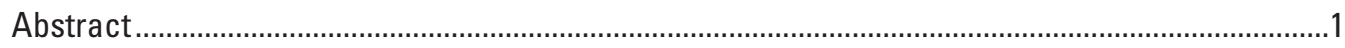

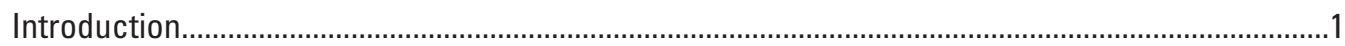

Description of Study Area ................................................................................................

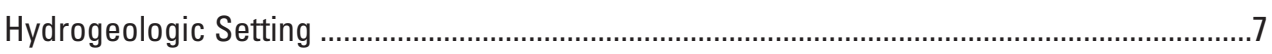

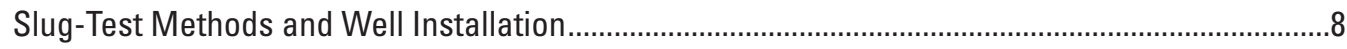

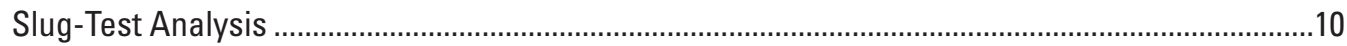

Hydraulic Conductivity of the Shallow Saturated Zone ........................................................12

Hydraulic Conductivity of the Deep Saturated Zone .............................................................12

Summary

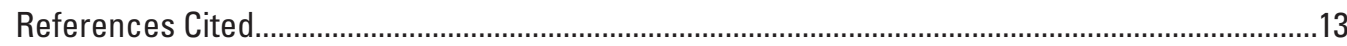

\section{Figures}

1. Map showing the location of the Hillview Reservoir study area and selected monitoring wells in Yonkers, Westchester County, and in Bronx County,

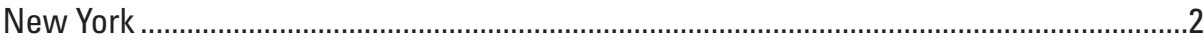

2. Map showing location of selected wells on the southern embankment at the Hillview Reservoir, Yonkers, Westchester County, New York ...........................................3

3. Hydrogeologic cross-section $D-D^{\prime}$ at the Hillview Reservoir in Westchester County,

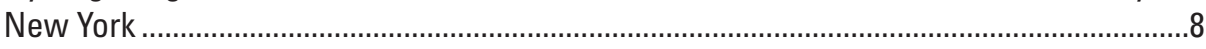

4. Schematic diagram showing the typical construction of a monitoring well at the Hillview Reservoir, Westchester County, New York, as constructed in 2001 ....................9

5. Straight line plots showing the results of the slug tests at wells $A, M B-4 \mathrm{~W}$, $B$, MR-100P, C, TB-18S, and D, TB-14D using the Bouwer and Rice (1976) method at the Hillview Reservoir, Westchester County, New York

\section{Table}

1. Information on selected monitoring wells at the Hillview Reservoir, Westchester County, New York 


\section{Conversion Factors}

U.S. customary units to International System of Units

\begin{tabular}{lll}
\hline \multicolumn{1}{c}{ Multiply } & \multicolumn{1}{c}{ By } & \multicolumn{1}{c}{ To obtain } \\
\hline inch (in.) & 2.54 & centimeter $(\mathrm{cm})$ \\
foot (ft) & 0.3048 & meter $(\mathrm{m})$ \\
acre & 0.004047 & square kilometer $\left(\mathrm{km}^{2}\right)$ \\
foot per day (ft/d) & 0.3048 & meter per day $(\mathrm{m} / \mathrm{d})$ \\
\hline
\end{tabular}

\section{Datum}

Vertical coordinate information is referenced to the National Geodetic Vertical Datum of 1929 (NGVD 29).

Horizontal coordinate information is referenced to the North American Datum of 1983 (NAD 83).

Elevation, as used in this report, refers to distance above the vertical datum.

\section{Abbreviations}

NYCDEP New York City Department of Environmental Protection

USGS U.S. Geological Survey 


\title{
Slug-Test Analysis of Selected Wells at an Earthen Dam Site in Southern Westchester County, New York
}

\author{
By Michael L. Noll, Anthony Chu, and William D. Capurso
}

\section{Abstract}

In 2005, the U.S. Geological Survey began a cooperative study with the New York City Department of Environmental Protection to characterize the local groundwater-flow system and identify potential sources of seeps on the southern embankment of the Hillview Reservoir in southern Westchester County, New York. The earthen embankment comprises low-permeability glacial clays that were excavated from the site and rest on a veneer of low-permeability glacial deposits that overlie crystalline bedrock. At least two groundwater-flow zones - one shallow and the other deep-overlie the bedrock at the reservoir. As part of the study, slug-test data from 38 screened wells were analyzed to determine the hydraulic conductivity of the sediments in the groundwater-flow zones. Slug-test data were collected from 12 wells at the Hillview Reservoir during August 2007 and from 25 wells at the reservoir and 1 monitoring well south of the reservoir in northern Bronx County in June 2012.

Hydraulic conductivity values at the reservoir ranged from 0.0012 to 2 feet per day. On the southern embankment, hydraulic conductivity ranged from 0.0026 to 1 foot per day for wells screened in the shallow saturated zone; 0.0012 to 2 feet per day for wells screened in the deep saturated zone; and 0.021 to 0.27 foot per day for wells screened in the toe of the southern embankment, where the deep and shallow saturated zones coalesce. A hydraulic conductivity of 0.016 foot per day was determined for a well partially screened in the crystalline-bedrock aquifer, which potentially indicates an interconnection of transmissive fractures near the bedrock surface. The results of four slug-out tests are also included in this report to quality assure the hydraulic conductivity estimates from the slug-in test analysis. The results of the four slug-out tests were within 8 percent of slug-in test results, with an average of less than 2 percent.

\section{Introduction}

The Hillview Reservoir in southern Westchester County, New York (fig. 1), which was constructed between 1913 and 1916, contains more than 900 million gallons of water and maintains a hydrostatic head of about 293 feet (ft) above the National Geodetic Vertical Datum of 1929 (NGVD 29). Ninety percent of the city's drinking water passes through the Hillview Reservoir facility from the Kensico Reservoir, which in turn is fed by the Delaware and Catskill aqueduct tunnels from upstate New York. Water is chlorinated at the reservoir and is piped from the southern end of the reservoir for distribution to users in New York City. The concrete-lined reservoir, which has an area of about 90 acres, is about equally divided into the East and West Basins by a concrete dividing wall. The Hillview Reservoir has operated continuously since the first aqueduct tunnel was completed in 1917 (Malcolm Pirnie, Inc. and TAMS Consultants, Inc., 2002).

The earthen embankment is composed of low-permeability glacial till and drift deposits that were excavated from the site and rest on a veneer of low-permeability glacial till that overlies crystalline bedrock. The earthen embankment was subsequently modified by other construction and maintenance projects near the downtake, uptake, and control chambers; connecting shafts; connecting conduits; the reservoir dividing wall; and the bypass tunnel (figs. 1 and 2).

To locate the potential sources of a continuous flowing seep downslope of the control chamber and at an elevation of approximately $255 \mathrm{ft}$ above NGVD 29 (fig. 2), the New York City Department of Environmental Protection (NYCDEP) installed 25 wells in 2000 and 2001 at the southern end of the reservoir, adding to the 32 wells previously installed around the reservoir. The NYCDEP approach included taking periodic depth-to-water measurements and sampling reservoir and spring water for major ions, however, results were inconclusive (Malcolm Pirnie, Inc. and TAMS Consultants, Inc., 2002).

In 2005, the U.S. Geological Survey (USGS) began a cooperative study with the NYCDEP to investigate the relevant hydrogeologic framework to characterize the local groundwater-flow system and to determine possible sources of the seep. In the study, data were collected between 2005 and 2008 and analyzed to evaluate the hydrology and geochemistry of the southern embankment and delineate the subsurface geology of the southern embankment from geophysical surveys (Chu and others, 2013).

Only 45 of the original 57 wells were available for slug tests because the remaining 12 wells (TB-3S, TB-14S, MR-131, HESF-8S, HESF-8D, 104-P, 106-PA, 110-P, 111, X, Y-PA, and PA) were decommissioned, damaged, or destroyed before or during the study period (table 1). In 2011, 


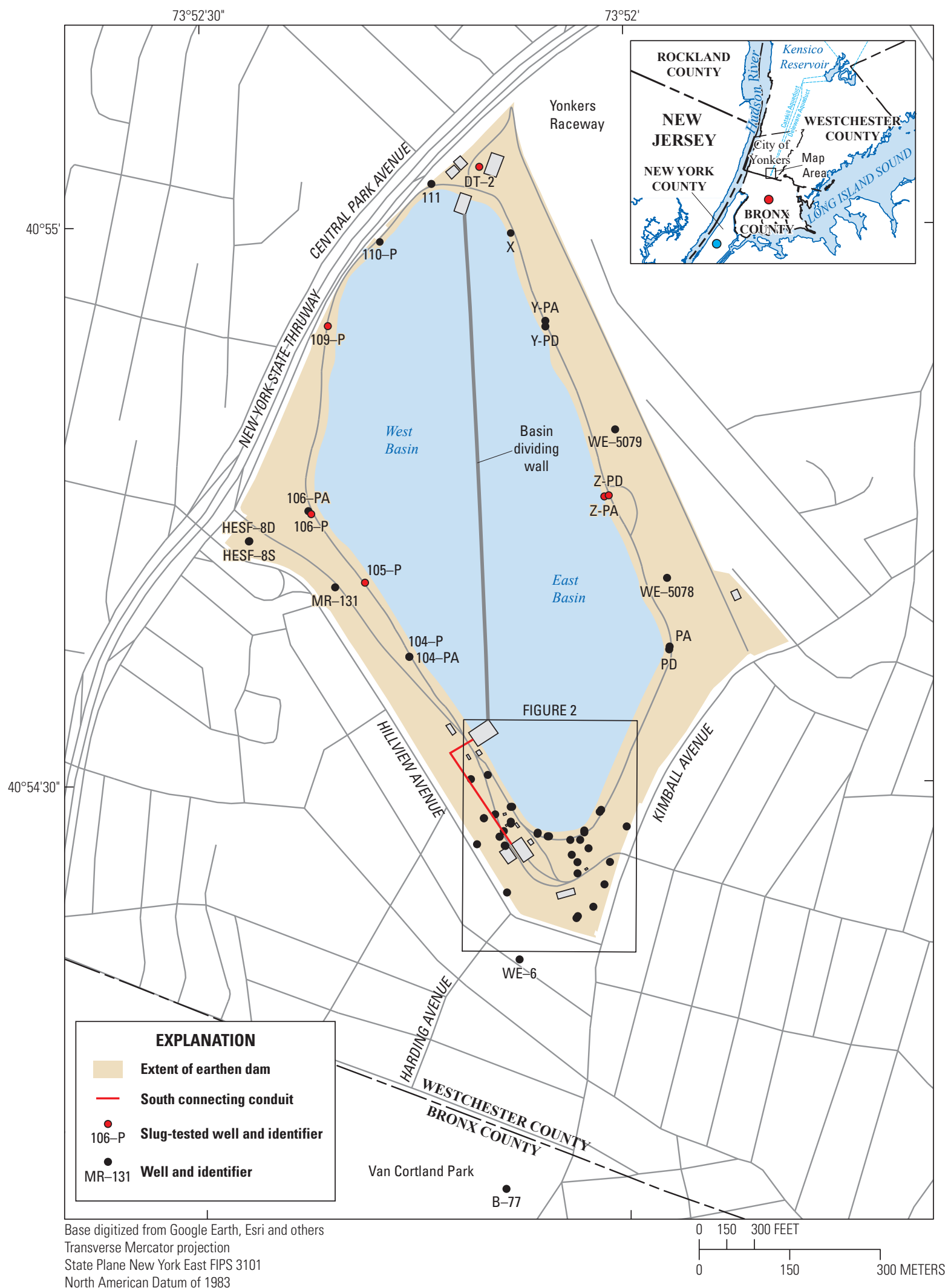

Figure 1. Location of the Hillview Reservoir study area and selected monitoring wells in Yonkers, Westchester County, and in Bronx County, New York. 


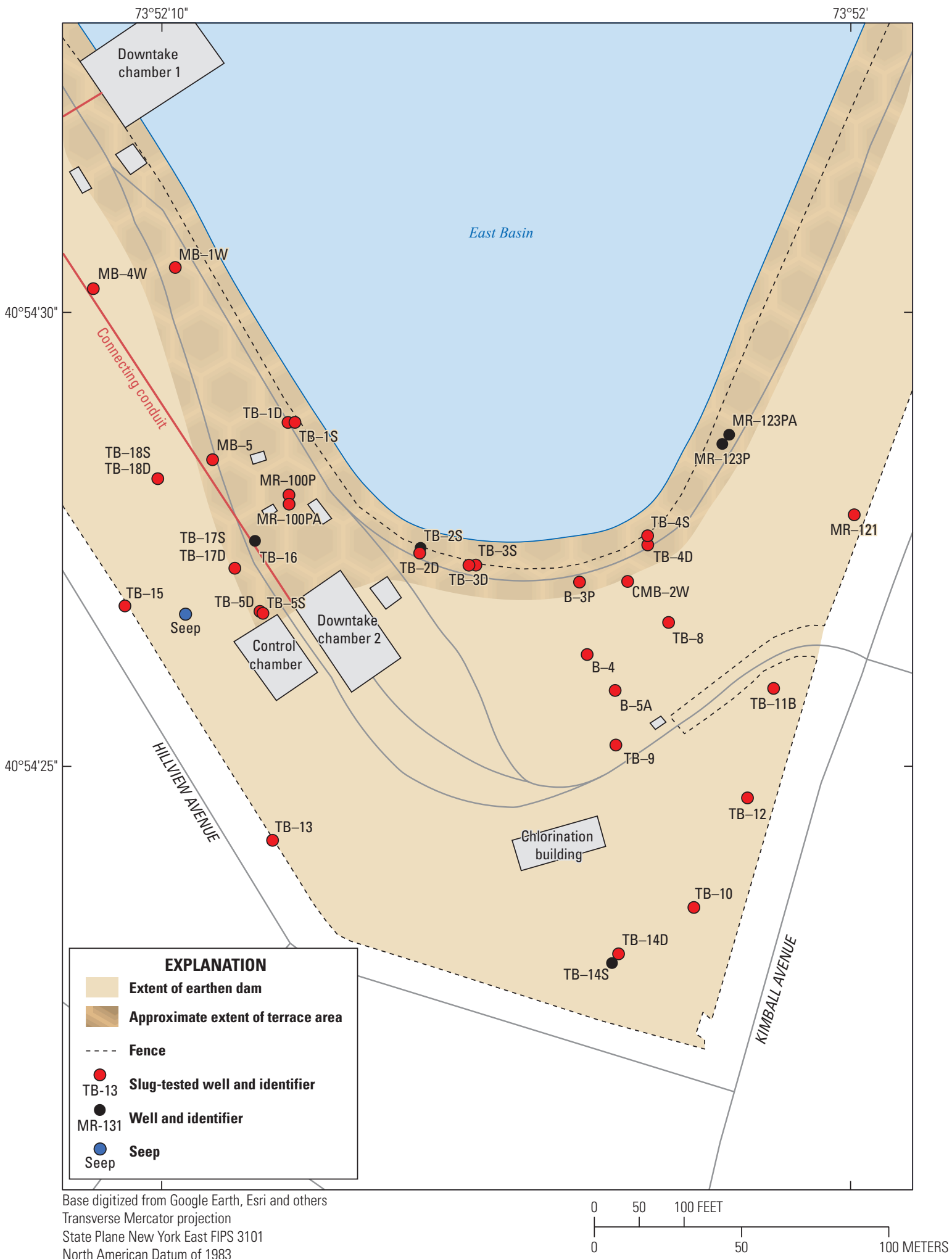

Figure 2. Location of selected wells on the southern embankment at the Hillview Reservoir, Yonkers, Westchester County, New York. 


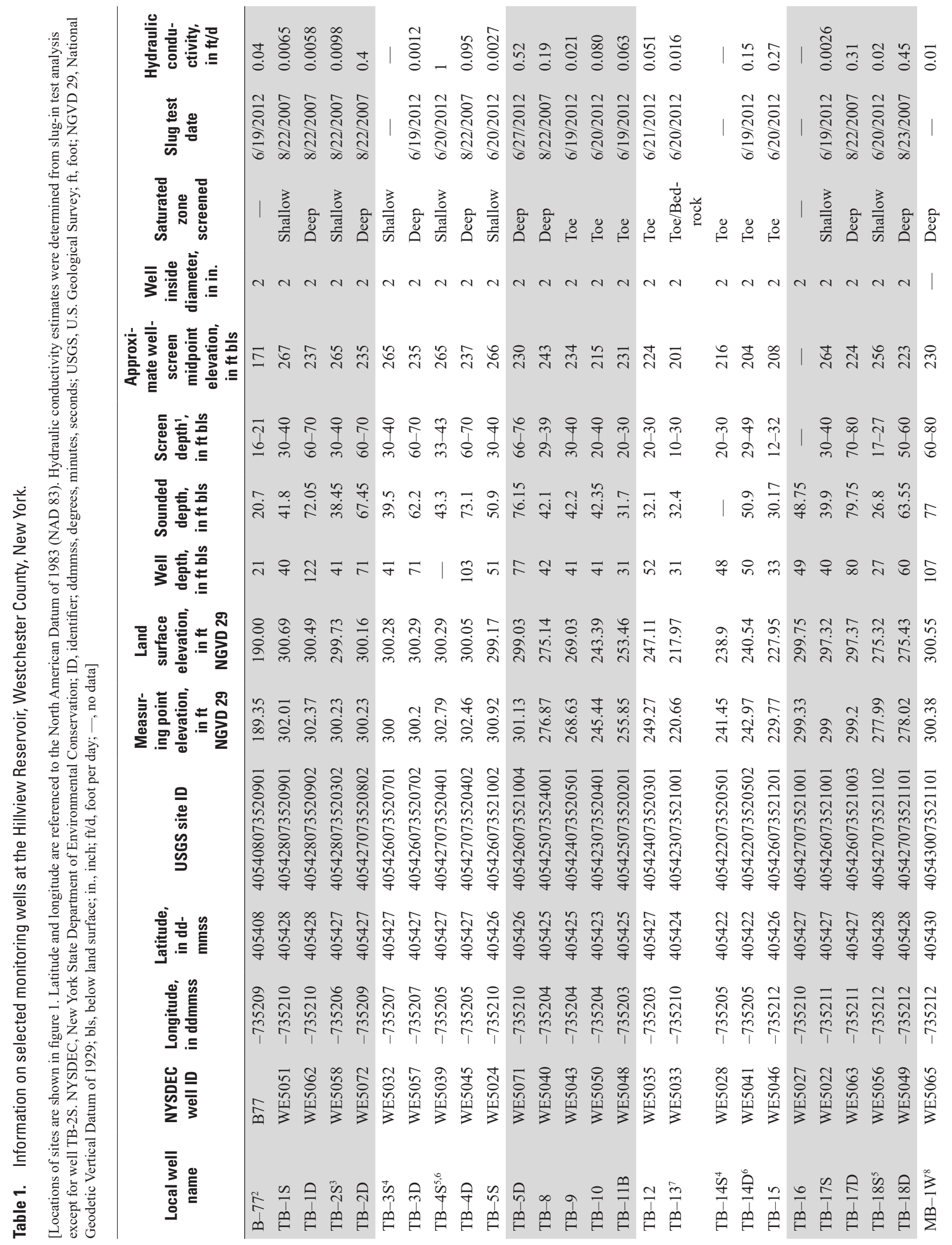




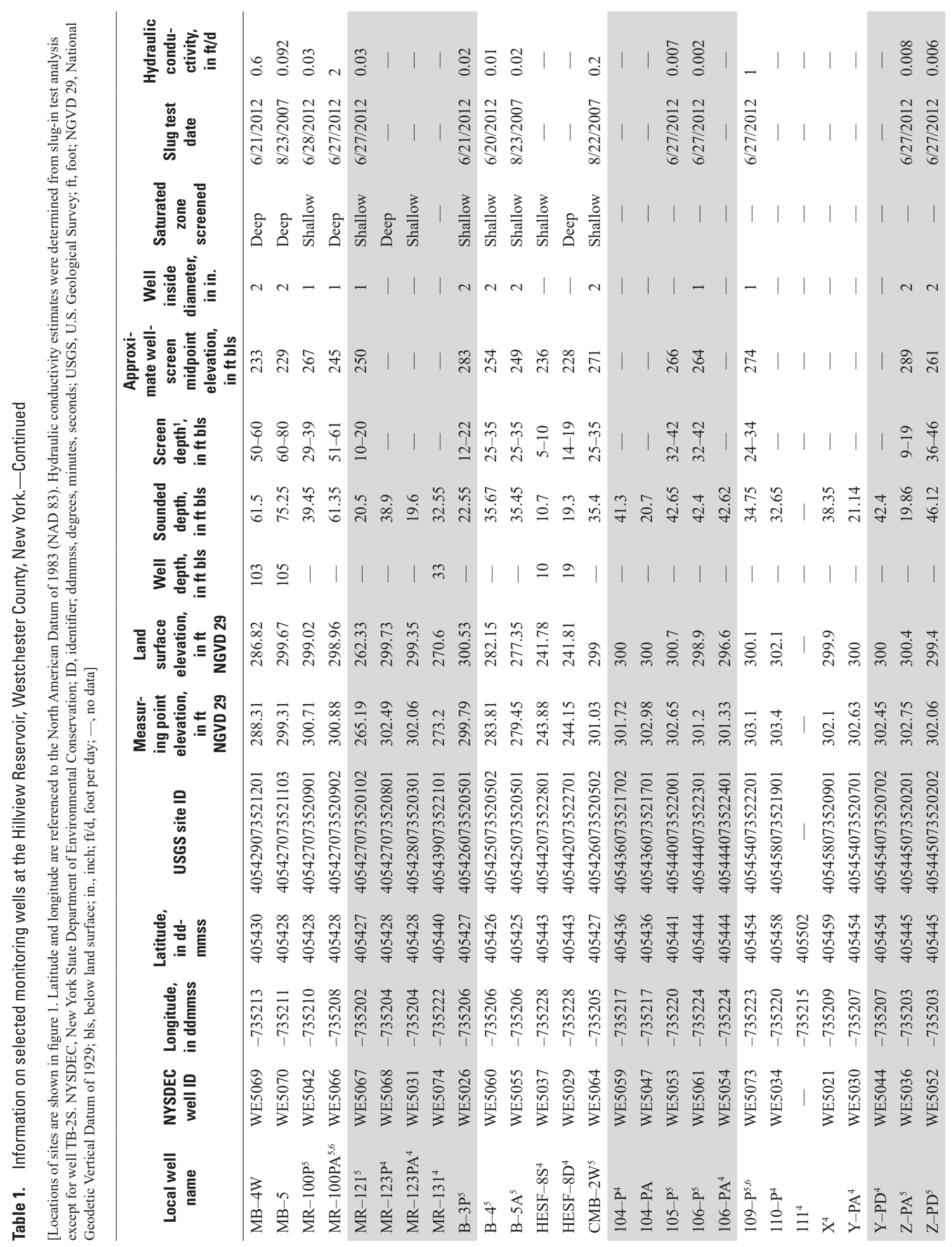




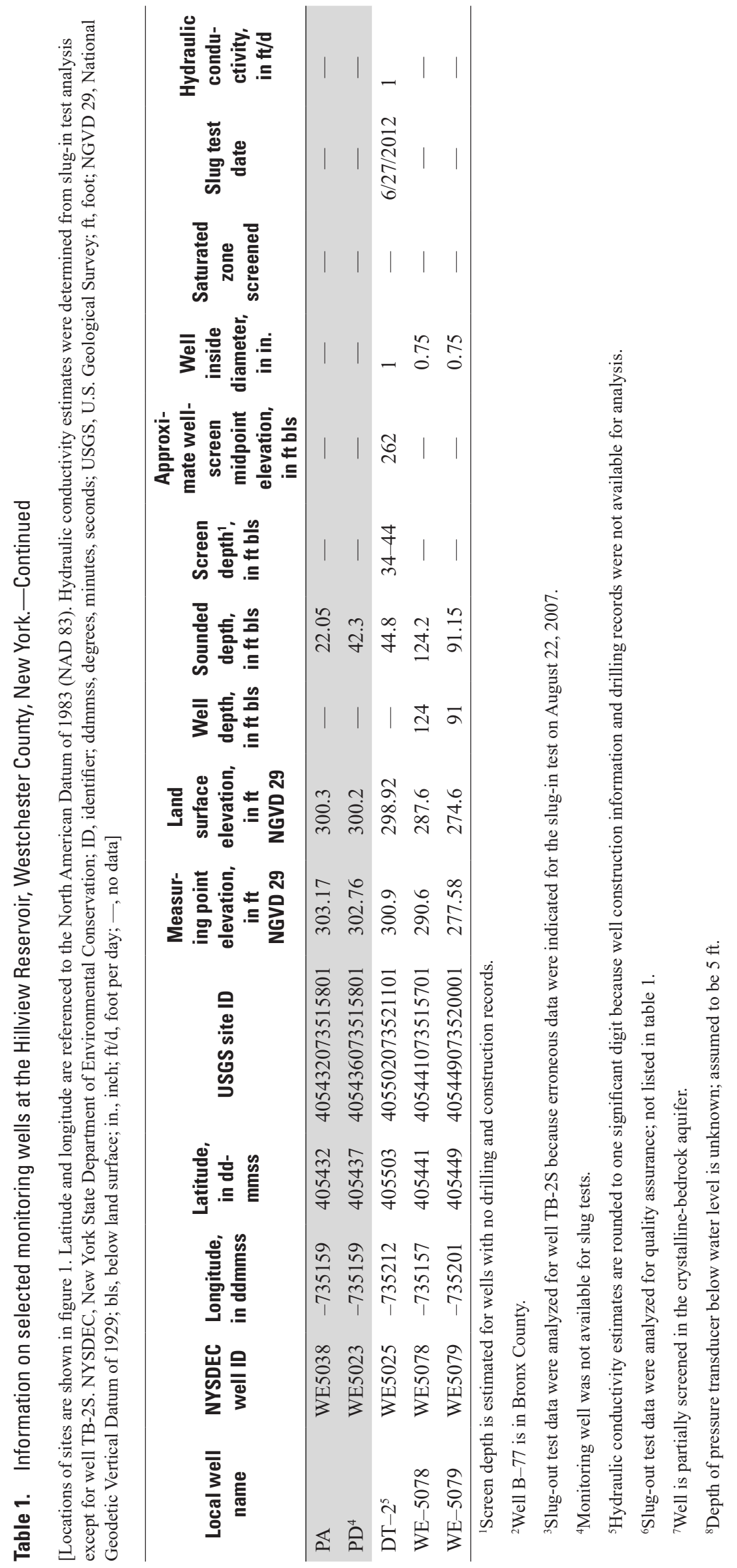


one additional well (B-77) was installed in northern Bronx County within Van Cortland Park, to supplement the existing monitoring network (fig. 1; table 1). Water-level displacement data were analyzed from 38 wells in the 46-well monitoring network to estimate the hydraulic conductivity of the earthen dam surrounding the East and West Basins and the embankment in the southernmost part of the site (figs. 1 and 2; table 1).

\section{Purpose and Scope}

The purpose of this report is to present the hydraulic conductivity estimates of the sediments of the earthen dam adjacent to the East and West Basins of the reservoir and the embankment on the southern part of the reservoir. The methods used to collect and analyze these data are also described in this report. Selected straight line plots showing the results of the slug tests are shown in illustrations. The complete set of test results is available in an associated USGS data release (Capurso and others, 2019).

\section{Description of Study Area}

The Hillview Reservoir in Yonkers in southern Westchester County was put into service in 1917 when the first water tunnel to New York City was completed. The reservoir has a surface area of more than 90 acres and contains more than 900 million gallons of water (fig. 1). The reservoir is bounded to the north and west by the New York State Thruway, to the north and east by the Yonkers Raceway and residential neighborhoods, to the south and east by residential neighborhoods along Kimball Avenue, and to the south and west by residential neighborhoods and a business district along Hillview Avenue.

\section{Hydrogeologic Setting}

The Hillview Reservoir study area is underlain by unconsolidated Holocene deposits, artificial fill (reworked glacial material), and glacial-drift deposits of Pleistocene age. These sediments consist of boulders, gravel, sand, silt, and clay, which are underlain by crystalline bedrock. The bedrock is permeable where transmissive fractures are present. In general, the bedrock forms a relatively impermeable base of the groundwater-flow system at the site (Chu and others, 2013).

The earthen embankment at the Hillview Reservoir consists of an assemblage of spoils from water-tunnel borings, modified glacial sediments, and an underlying layer of Pleistocene glacial till deposits. The groundwater levels within the earthen embankment at the Hillview Reservoir are affected by recharge from precipitation and the water surface elevations of the reservoir basins. Water levels at the reservoir fluctuate as a result of water use and refilling of the basins during daily cycles. This cyclic demand produces an artificial diurnal load on the surrounding embankment materials and local groundwater-flow system.

Southern Westchester County is underlain by a highgrade metamorphic bedrock sequence consisting of gneiss, schistose-gneiss interlayered with granite, and marble (Asselstine and Grossman, 1955; Baskerville, 1982, 1992). The bedrock in southern Westchester County consists of a series of northeast-trending ridges and valleys. The ridges generally are underlain by gneiss and granite (Asselstine and Grossman, 1955; Baskerville, 1982). The Hillview Reservoir is on a ridge that is underlain by gneiss that probably is the Yonkers Gneiss or Fordham Gneiss (Chu and others, 2013). The bedrock contains many fractures, some of which are transmissive. The gneiss is considered a poor-to-moderate groundwater producer, whereas the marble is the most productive bedrock in Westchester County (Asselstine and Grossman, 1955). Depth to bedrock ranges from less than 1 to $125 \mathrm{ft}$ below land surface within the southern part of Westchester County; however, records of wells installed along the low-lying areas, adjacent to the toe of the dam, and northern areas of the reservoir indicate that the depth to bedrock at those areas is about $20 \mathrm{ft}$. The thickness of the till at the reservoir was estimated to be between 45 and $70 \mathrm{ft}$ (Malcolm Pirnie, Inc., and TAMS Consultants, Inc., 2002).

At least two groundwater-flow zones - one shallow and the other deep - are present at the study area (fig. 3). Wells in the shallow flow zone have the highest water levels, are only slightly affected by reservoir water-level cycles, and respond to substantial precipitation events. In contrast, wells in the deep flow zone have low water-level elevations, are highly affected by reservoir water-level cycles, and respond only slightly to precipitation-induced recharge (Chu and others, 2013). The hydrogeology of these saturated zones was delineated in an original engineering design drawing of Hillview Reservoir (Board of Water Supply of the City of New York, 1909), which indicated highly impermeable and compacted material in the shallow saturated zone ("special impervious embankment") adjacent to the reworked but uncompacted embankment material ("ordinary embankment") comprising the slopes; both embankments overlie the deep zone (fig. 3). The deep zone is made up of unmodified glacial sediments (glacial till) with a thin basal layer of coarse sediments that lie upon granitic bedrock. The approximate elevation of the hydrogeologic contact between the deep and shallow zones is $250 \mathrm{ft}$ above NGVD 29. The deep (and shallow) saturated zone may extend beyond the indicated geographic limits, but without additional monitoring wells this hypothesis cannot be validated.

The deep and shallow saturated zones coalesce into a single groundwater-flow system at the toe of the embankment, which is made up of reworked, coarse material that lie upon the unmodified glacial sediments at depth. In general, the coarse surficial material identified as "rock-fill and earth embankment" in original construction drawings was excavated and placed on top of the glacial sediments near the toe of the dam during the construction of the Hillview Reservoir (Board of Water Supply of the City of New York, 1929). 


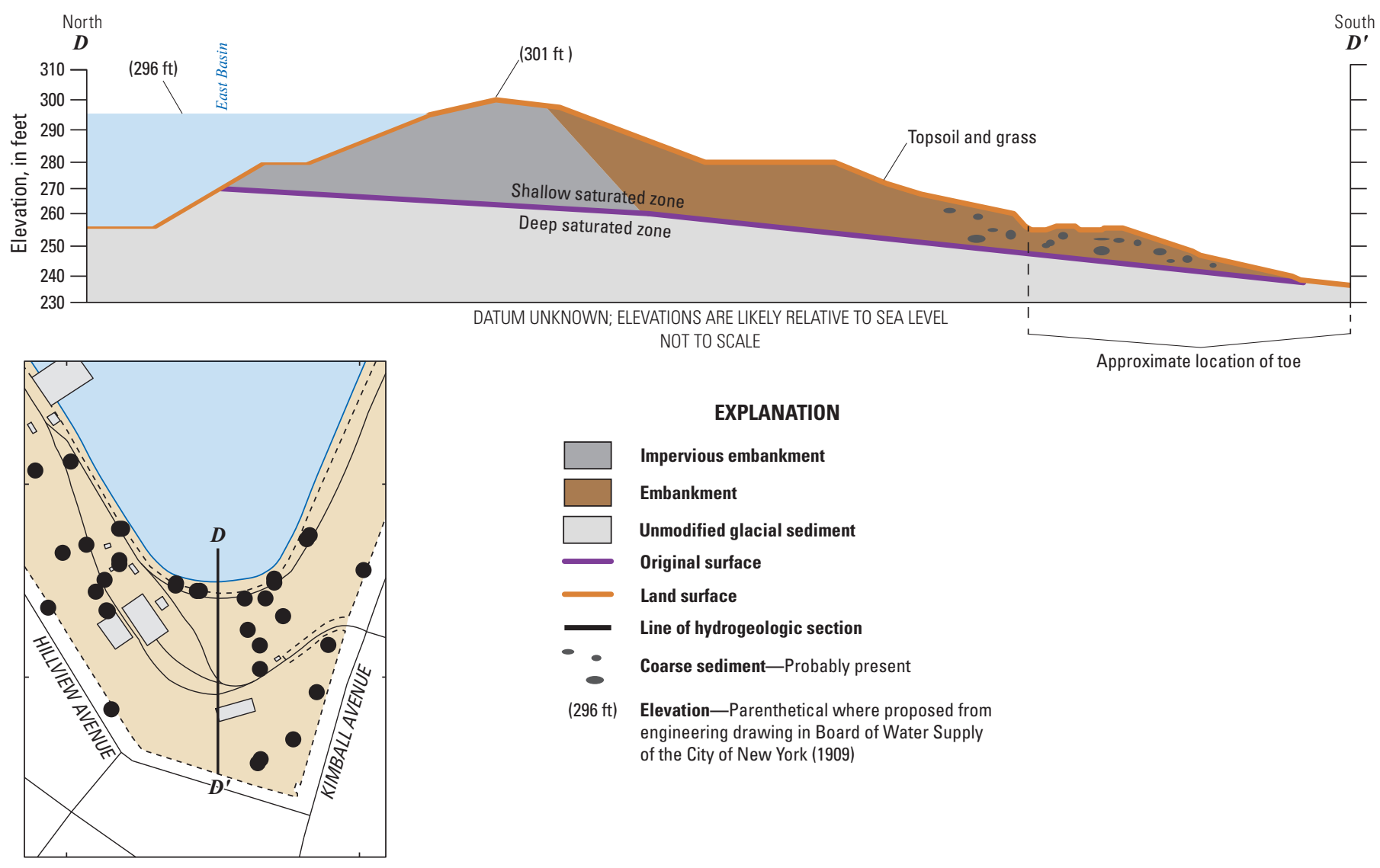

Figure 3. Hydrogeologic cross-section $D-D^{\prime}$ at the Hillview Reservoir in Westchester County, New York; modified from engineering drawing in Board of Water Supply of the City of New York (1909). Elevations in parentheses.

\section{Slug-Test Methods and Well Installation}

Water displacement tests, commonly known as "slug tests," were conducted in 25 wells at the Hillview Reservoir and 1 monitoring well (B-77) in Bronx County in June 2012 to estimate the hydraulic conductivity of the saturated zones within the earthen embankment (figs. 1 and 2; table 1). The water in the well was displaced by a solid object, called a slug, and the water-level recovery was measured as a function of time. Hydraulic conductivity, which is a measure of the capacity of sediments adjacent to the screened interval to transmit water, was estimated based on an analysis of the rate of waterlevel recovery in the well.

The slugs consisted of 1.07-inch (in.)-diameter (outside dimension) polyvinyl chloride (PVC) pipes (schedule 40) that were filled with sand and capped at both ends. The slugs were suspended in the wells by a polypropylene rope attached to an eye bolt at the top of each slug, and the rope was secured to a section of pipe at the top of the well. An approximately 0.5 -in.-diameter fiberglass slug was used to test monitoring wells that have a 1-in. diameter. The length of the PVC slugs ranged from 5 to $7 \mathrm{ft}$, and the fiberglass slugs were typically 4 to $6 \mathrm{ft}$ long. When a slug is quickly inserted in the well below the static water level, the water level rapidly rises, then, as water escapes the well through the screen into the aquifer because of the increased hydraulic head, the water level falls back toward the original static water level (also called a falling-head or slug-in test). When a slug is rapidly removed from below the water surface, the water surface rapidly falls, then, as water comes in through the screen from the surrounding aquifer material, the water level rises toward the original static water level (also called a rising-head or slug-out test).

Prior to the start of the slug test, a vented submersible pressure transducer was suspended in the water column by a cable that was secured at the top of the well. The water level in the well was allowed to reach equilibrium after the insertion of the sensor (which may displace water in the well) before beginning the test. Pressure measurements by the transducer 
were converted to depth-to-water based on the manual depthto-water measurement taken by the operator prior to the start of the test. The accuracy of a pressure transducer, rated at 15 pounds per square inch $\left(\mathrm{lb} / \mathrm{in}^{2}\right)$, is approximately $0.05 \mathrm{ft}$ (In-Situ Inc., 2015). Before the insertion (or removal) of the slug, data loggers were programmed to record data on a logarithmic time scale. Depth-to-water data were measured by the pressure transducer every 0.004 second at the beginning of the test, with the sampling interval between measurements increasing logarithmically to 1 minute after 15 minutes. This sampling interval provided detailed data coverage during the early part of the slug test and less detailed coverage during the latter part of the test, when less change was expected. The data loggers were started a few seconds before the insertion (or removal) of the slug to record the background water level and to ensure that the exact time the slug was inserted (or removed) was recorded. After the end of the test, the waterlevel data were downloaded to a computer and analyzed using commercially available slug-test analysis software (Duffield, 2007). The volume of the data logger cable was not accounted for during analysis so hydraulic conductivity values may be slightly higher than reported.

Rapid fluctuations of water levels (noise) in the well from an improperly inserted slug can adversely affect the quality of the early-time water-level displacement data and make it difficult to interpret, so care was taken by the operator during the insertion (or removal) of the slug to reduce noise in the water levels. After the slug was inserted (or removed), the well was allowed to recover without any outside influence. The slug tests were stopped when the rate of change was less than or equal to 0.01 foot per 10 minutes (Cunningham and Schalk, 2011). Data from slug-out tests were also analyzed to validate the slug-in test results from wells TB-4S, TB-14D, MR-100PA, and 109-P.

Monitoring wells were installed using auger or rotary drilling methods. During drilling, core samples were taken with a split spoon or Shelby tube sampler at variable intervals; the borehole diameter was typically 4.75 in. Monitoring wells were typically constructed of 2-in.-inside-diameter PVC riser pipe attached to a slotted screen that was capped at the bottom of the well (fig. 4). The annular space around the well screen (between the borehole and well) was filled with a sand pack, which was sealed with bentonite pellets at the top of the screen zone. A bentonite-concrete mixture was used to fill the annular space adjacent to the riser pipe and was capped at land surface with a concrete seal. The inside diameter of the tested wells was variable and ranged from 0.75 to 2 in. (table 1 ). Well construction data and drilling and well installation records for 15 of the monitoring wells were not available, therefore some assumptions were made to analyze the water-level data from these wells. These wells are TB-4S, TB-18S, MR-100P, MR-100PA, MR-121, B-3P, B-4, B-5A, CMB-2W, 105-P, 106-P, 109-P, Z-PA, Z-PD, and DT-2 (table 1). Hydraulic conductivity estimates for the 15 wells are reported to one significant figure to indicate the increased uncertainty of the analysis.

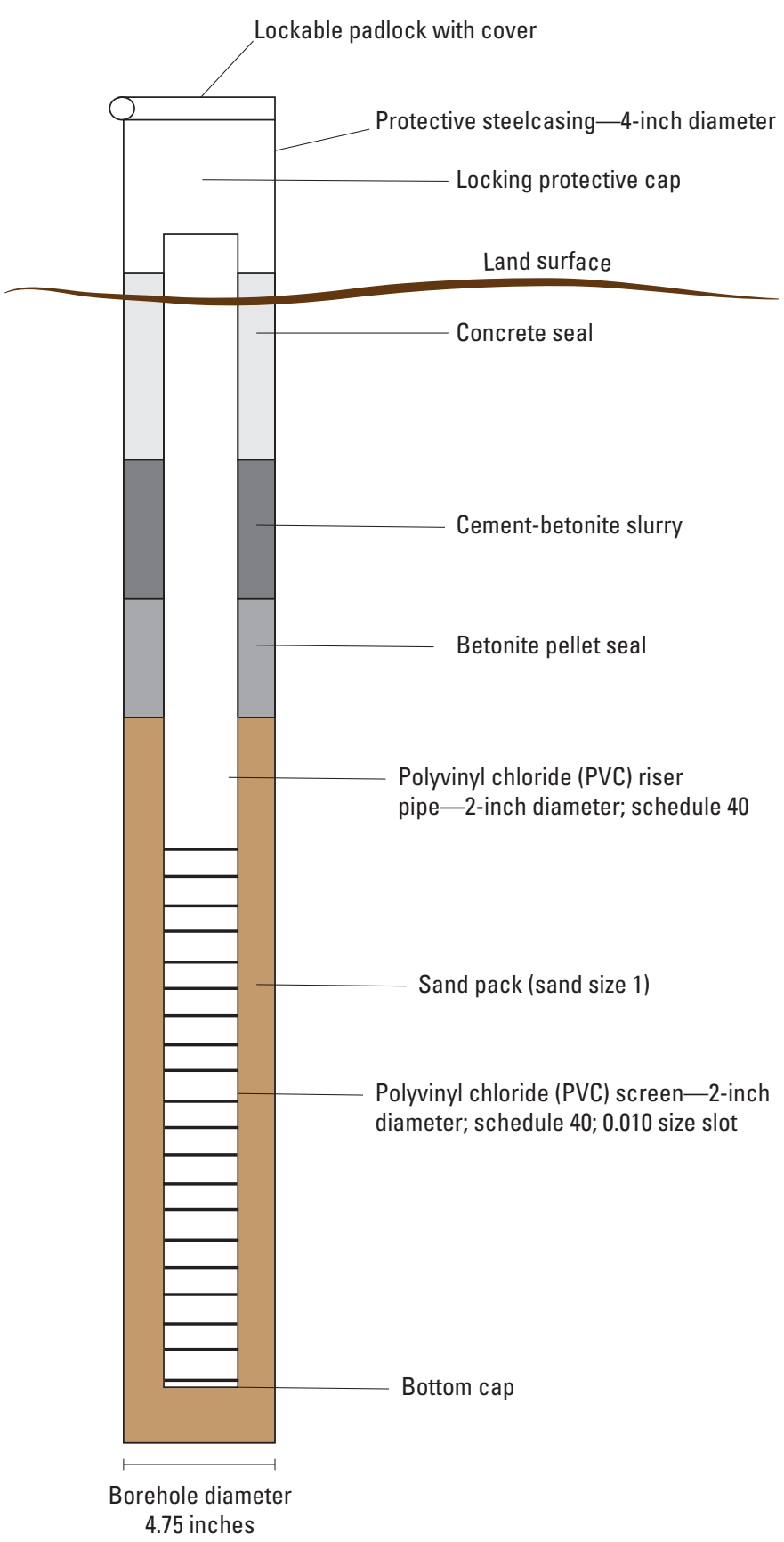

Figure 4. The typical construction of a monitoring well at the Hillview Reservoir, Westchester County, New York, as constructed in 2001. 


\section{Slug-Test Analysis}

Slug tests were performed in June 2012 at 25 wells within the area of the Hillview Reservoir and 1 monitoring well (B-77) in northern Bronx County to determine the hydraulic conductivity of the sediments adjacent to the well screens (figs. 1 and 2; table 1). Data from these 26 tests along with 12 additional slug tests that had been performed at the reservoir in August 2007 were analyzed using the Bouwer and Rice (1976) method with commercially available hydraulic test analysis software (Duffield, 2007). The Bouwer and Rice method makes the following assumptions:

- the aquifer is unconfined and has an infinite areal extent,

- the aquifer is homogeneous and uniform in thickness,

- flow to the well is in a quasi-steady state (storage is negligible), and

- insertion or withdrawal of the slug is instantaneous.

The ratio of the change in water level to the initial change in water level after the insertion of the slug was plotted log-linearly as a function of time. A line was fit to the data points.

Hydraulic conductivity can be estimated from the slope of the fitted line using the aquifer characteristics, such as the saturated thickness and vertical and horizontal anisotropy, and the well construction information, such as the radius of the well casing and the length and depth of the well screen (Bouwer and Rice, 1976). The method was later modified and adopted for confined aquifers, while also accounting for the effects of filter pack drainage (Bouwer, 1989). Straight line plots for the 38 monitoring wells indicating the results of the slug-in tests using the Bouwer and Rice method are reported in a USGS data release (Capurso and others, 2019); for well TB-2S, the data analyzed were from a slug-out test because the slug-in test at the well on August 22, 2007, indicated erroneous data. The hydraulic conductivity results of four slug-out tests for monitoring wells TB-4S, TB-14D, MR-100PA, and 109-P are $1,0.14,2$, and 1 feet per day (ft/d), respectively (fig. 5; Capurso and others, 2019). These tests were used to validate and quality assure the hydraulic conductivity estimates from the slug-in test results. The percent differences between the slug-in and slug-out test results were $0,0,0$, and 7 percent for wells TB-4S, MR-100PA, 109-P, and TB-14D, respectively. Straight line plots of three representative wells for slug-in tests (MB-4W, MR-100P, and TB-18S) and one representative well for a slug-out test (TB-14D) are shown in figure 5 of this report.

The shallow saturated and toe zones are considered unconfined water-bearing units; the deep saturated zone is considered a confined water-bearing unit but is hydraulically connected to the shallow saturated zone above the adjacent toe zone (table 1; Noll and others, 2018). The bedrock surface is considered the bottom of the water-bearing unit for both shallow and deep saturated zones. Drilling logs indicate bedrock surface elevations of 182, 196, 199, 199, 199, 200, 200, 203, 204, 222, and $229 \mathrm{ft}$ above NGVD 29 for wells TB-1D, TB-13, MB-1W, MB-4W, MB-5, TB-14D, TB-15, TB-12, TB-4D, TB-11, and CMB-2W, respectively. A median bedrock surface elevation of $200 \mathrm{ft}$ above NGVD 29 was used as the inferred bedrock elevation for tested wells with no drilling records.

The saturated thickness of the deep saturated zone was determined by subtracting the known (or inferred) bedrock surface elevation from the elevation of the top of the deep saturated zone (approximately $250 \mathrm{ft}$ above NGVD 29). The estimated thickness of the deep water-bearing unit within the Hillview Reservoir ranges from 46 to $68 \mathrm{ft}$, with the smallest and greatest values at wells TB-4D and TB-1D, respectively. The saturated thicknesses of the shallow saturated and toe zones were determined by subtracting the bedrock surface elevation from the inferred water table elevation near the tested well (Chu and others, 2013; Noll and Chu, 2018). The estimated thicknesses of the shallow saturated and toe zones within the Hillview Reservoir ranged from 14 to $96 \mathrm{ft}$, with the smallest and greatest values at wells TB-14D and TB-1S, respectively.

Because the earthen embankment is made up of relatively homogeneous material (modified and unmodified glacial clays), an anisotropy of 1 was used for analysis. Well TB-13 has a 20-ft-long well screen, which is partially in the crystalline-bedrock aquifer and the unconsolidated toe zone (table 1); analysis of the continuous-record hydrograph from well TB-13 indicates the water table is in the bedrock aquifer (Noll and Chu, 2018). A saturated thickness of $100 \mathrm{ft}$ and anisotropy of 1 were assumed for well TB-13 because no information was available that indicated the permeability of the bedrock aquifer near the well screen at approximately $200 \mathrm{ft}$ above NGVD 29. Well-screen elevations were determined by subtracting the elevation of the midpoint of the well screen from the measuring point elevation. Screen elevations for wells within the reservoir ranged from 201 to $289 \mathrm{ft}$ above NGVD 29, with the lowest and highest values at wells TB-13 and Z-PA, respectively (table 1).

Well B-77 was used as a control well to evaluate the hydraulic conductivity of the local glacial till, which would provide a point of comparison for the modified till at sections of the embankment material at the Hillview Reservoir. Analysis of the slug test at B-77 (Capurso and others, 2019) in Van Cortland Park in Bronx County, indicated a hydraulic conductivity of $0.042 \mathrm{ft} / \mathrm{d}$, which is within the typical range of glacial till noted by Freeze and Cherry (1979) and consistent with the geology recorded during well construction (table 1). The hydraulic conductivities at six wells (TB-2D, TB-4S, TB-5D, TB-18D, MB-4W, and MR-100PA) on the southern embankment are approximately one to two orders of magnitude greater than the control measurement. Well 109-P near the northwestern part of the reservoir and well DT-2 at the northernmost point within the reservoir near downtake chamber 2 also yielded hydraulic conductivities approximately two orders of magnitude greater than the control well. For the 


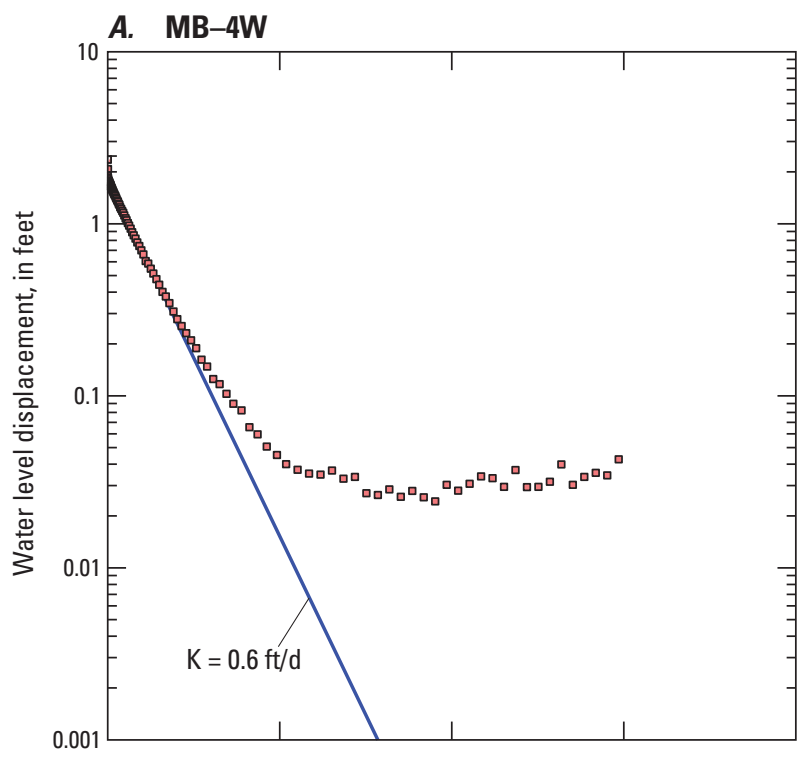

\section{B. MR-100P}

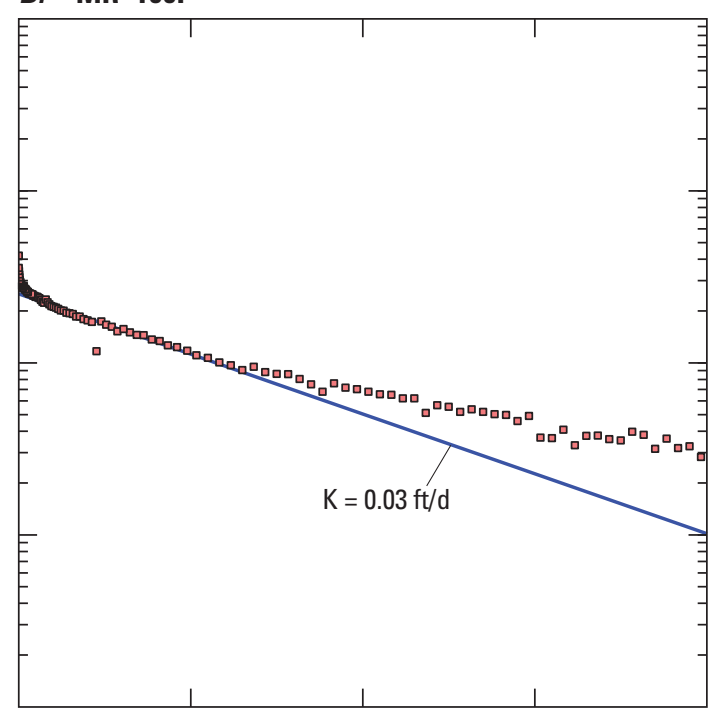

D. TB-14D
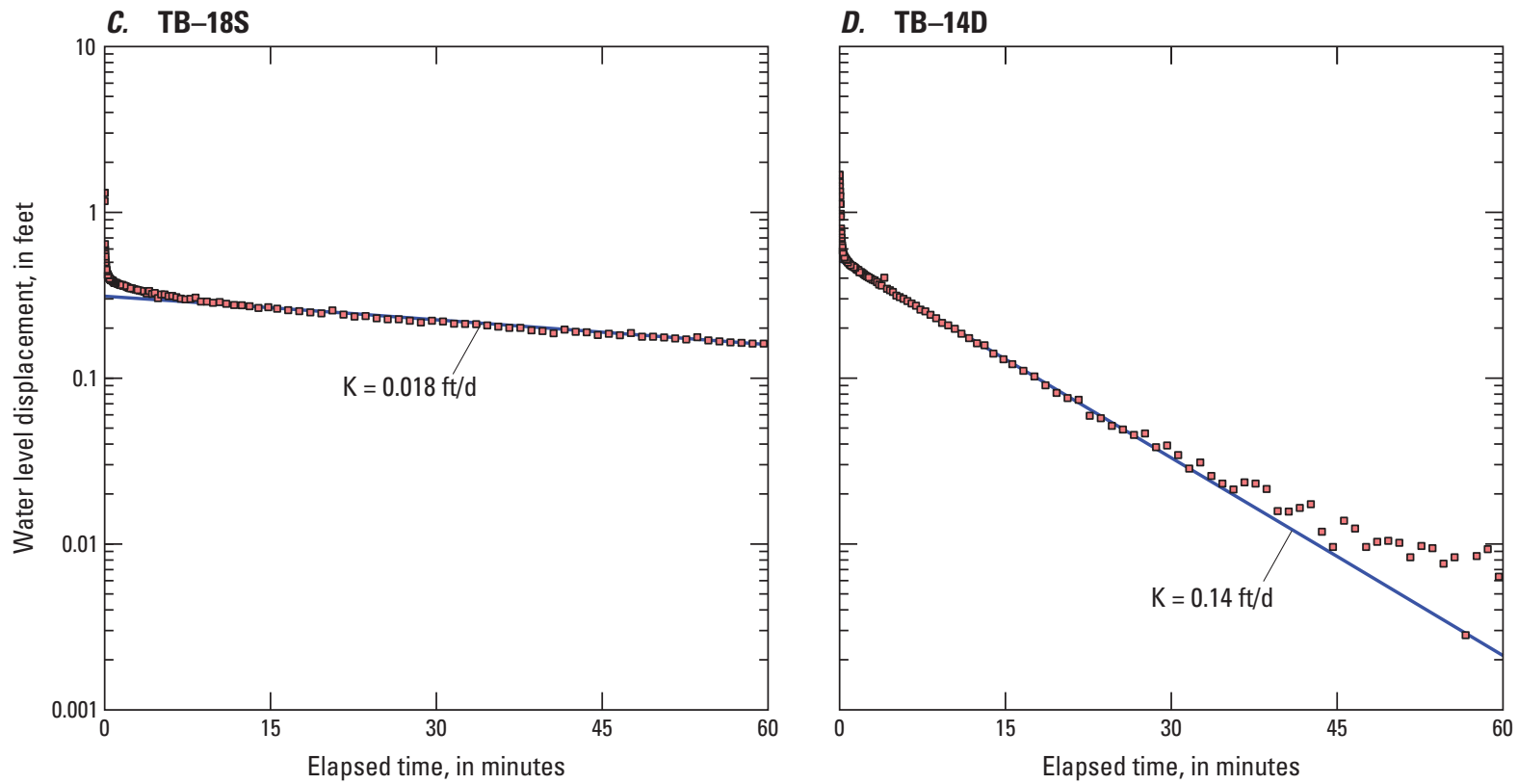

EXPLANATION

- Straight line plot

- Water level

displacement

Figure 5. The results of the slug tests at wells $A, \mathrm{MB}-4 \mathrm{~W}, B, \mathrm{MR}-100 \mathrm{P}, C$, TB-18S, and D, TB-14D using the Bouwer and Rice (1976) method at the Hillview Reservoir, Westchester County, New York. Well TB-14D is a slug-out test. K, estimated hydraulic conductivity; $\mathrm{ft} / \mathrm{d}$, foot per day. 
slug-test analysis of monitoring well B-77, an anisotropy of 1 and saturated thickness of $8 \mathrm{ft}$ were used; the well screen elevation is approximately $171 \mathrm{ft}$ above NGVD 29.

Hydraulic conductivity values for the 37 wells within the Hillview Reservoir (not including the monitoring well in Bronx County) that were slug tested ranged from 0.0012 to $2 \mathrm{ft} / \mathrm{d}$, with the lowest and highest values at wells TB-3D and MR-100PA, respectively. The mean hydraulic conductivity for the wells within the Hillview Reservoir that were slug tested was $0.2 \mathrm{ft} / \mathrm{d}$, with a standard deviation of $0.4 \mathrm{ft} / \mathrm{d}$. Thirty-one of the 38 tested wells are screened in the southern embankment.

\section{Hydraulic Conductivity of the Shallow Saturated Zone}

The shallow saturated zone at the southern embankment of the Hillview Reservoir is approximately defined as the uppermost $45 \mathrm{ft}$ of the embankment materials below the crest of the reservoir (Chu and others, 2012). In general, the easternmost extent of the shallow system is near well MR-121, approximately $400 \mathrm{ft}$ north of the chlorination building, and the westernmost extent is near wells TB-18S and TB-15, approximately $200 \mathrm{ft}$ west of downtake chamber 2 (fig. 2). The shallow system is generally bounded to the north by the East Basin and to the south by the toe of the southern embankment where the deep and shallow saturated zones converge (fig. 3). Slug-test analysis of 12 wells screened in the shallow water-bearing unit indicated that hydraulic conductivity ranged from 0.0026 to $1 \mathrm{ft} / \mathrm{d}$, with the lowest and highest values at wells TB-17S and TB-4S, respectively (table 1); the average hydraulic conductivity was $0.1 \mathrm{ft} / \mathrm{d}$, with a standard deviation of $0.3 \mathrm{ft} / \mathrm{d}$.

\section{Hydraulic Conductivity of the Deep Saturated Zone}

The top surface of the deep saturated zone within the southern embankment is approximately $50 \mathrm{ft}$ below the crest of the dam or $250 \mathrm{ft}$ above NGVD 29, and its base is defined by the relatively impermeable crystalline-bedrock surface beneath the Hillview Reservoir. Drilling logs from 12 wells indicated that the bedrock surface is variable and ranges from 182 to $229 \mathrm{ft}$ above NGVD 29, with the lowest and highest values at wells TB-1D and CMB-2W, respectively. In general, the easternmost extent of the deep system is near wells TB-4D and TB-8, approximately $300 \mathrm{ft}$ north of the chlorination building, and to the west near wells MB- $1 \mathrm{~W}$ and MB-4W, approximately $150 \mathrm{ft}$ south of downtake chamber 1 (figs. 1 and 2). Similar to the shallow system, the deep system is generally bounded to the north by the East Basin and to the south by the toe of the southern embankment where the deep and shallow saturated zones coalesce into a single groundwater-flow system (fig. 3). Hydraulic conductivity estimates at the 12 deep system wells on the southern embankment ranged from 0.0012 to $2 \mathrm{ft} / \mathrm{d}$, with the lowest and highest values at wells TB-3D and MR-100PA, respectively. Of the 12 deep system wells, wells TB-1D, TB-2D TB-3D, TB-5D, TB-17D, TB-18D, MR-100PA, MB-1W, MB-4W, and $\mathrm{MB}-5$ are screened on the western side of the southern embankment; wells TB-4D and TB- 8 are screened in the deep system on the eastern side of the southern embankment. The average hydraulic conductivity of the 12 tested wells was 0.4 $\mathrm{ft} / \mathrm{d}$, with a standard deviation of $0.6 \mathrm{ft} / \mathrm{d}$. In general, the permeability of the deep saturated zone is higher and more variable than that at the shallow and toe zones. Of the 31 tested wells on the southern embankment, 6 of the highest 7 hydraulic conductivity wells are screened in the deep saturated zone on the western side of the southern embankment in proximity to the south connecting conduit.

Well MR-100PA has the highest hydraulic conductivity $(2 \mathrm{ft} / \mathrm{d})$ of the wells that were slug tested at the Hillview Reservoir. Because of the relatively high permeability indicated by the results of the initial slug test, data from a slug-out test were also analyzed and yielded a hydraulic conductivity of $2 \mathrm{ft} / \mathrm{d}$. Qualitative observations during water-quality sampling, which requires purging three casing volumes of water from the well using an open-top bailer for low-permeability formations, indicate a relatively rapid recovery of water levels in well MR-100PA. For both the slug-out and the slug-in tests, water levels in well MR-100PA recovered relatively rapidly - within 4 minutes. Furthermore, a hydraulic conductivity on the order of $1 \mathrm{ft} / \mathrm{d}$ seems to verify the hypothesis that relatively permeable sediments exist at depth beneath the terrace area (fig. 2) on the western side of the southern embankment, which may influence local flow regimes.

Slug-test analysis of six wells (TB-9, TB-10, TB-11B, TB-12, TB-14D, and TB-15) screened in the toe of the southern embankment were used to help determine the variability of hydraulic conductivity in the deep and shallow saturated zones. These wells are screened where the shallow and deep saturated zones coalesce near the toe of the southern embankment along Hillview Avenue, on the western and southern side, and Kimball Avenue, on the eastern side (figs. 1 and 2). Hydraulic conductivity of the sediments of the embankment material near the toe of the earthen dam ranged from 0.021 to $0.27 \mathrm{ft} / \mathrm{d}$, with the lowest and highest values at wells TB-9 and TB-15, respectively. The average hydraulic conductivity of the six tested wells was $0.1 \mathrm{ft} / \mathrm{d}$. Well-screen elevations ranged from approximately 204 to $234 \mathrm{ft}$, with the lowest and highest values at wells TB-14D and TB-9, respectively.

The water level response in well TB-13 indicates a potential interconnection of transmissive fractures near the surface of the crystalline-bedrock aquifer. For example, water levels respond relatively rapidly to recharge events such as precipitation and upgradient groundwater flow (Chu and others, 2013; Noll and Chu, 2018). The estimated hydraulic conductivity of $0.016 \mathrm{ft} / \mathrm{d}$ at well TB-13 is within the range of fractured igneous and metamorphic rock (Freeze and Cherry, 1979). 


\section{Summary}

In 2000 and 2001, the New York City Department of Environmental Protection drilled 25 wells at the southern end of the Hillview Reservoir to supplement the 32 wells previously installed around the reservoir (total of 57 wells in the monitoring network) to locate potential sources of a continuous flowing seep. Monitoring wells were installed using auger or rotary drilling methods, and core samples were taken at variable intervals. Monitoring wells were typically constructed of 2-inch-diameter polyvinyl chloride (PVC) riser pipe attached to a slotted screen that was capped at the bottom of the well; however, well construction records for 15 monitoring wells were not available, therefore some assumptions were required to analyze the water-level data from these wells.

In June 2012, 25 single-well slug tests were performed at the reservoir and 1 in Bronx County. Twelve additional singlewell slug tests were completed at the reservoir in August 2007. Hydraulic conductivity was calculated based on the rate of recovery in the well.

The earthen embankment is made up of low-permeability glacial clays that were excavated from the site and rest on a veneer of low-permeability glacial deposits that overlie crystalline bedrock. At least two groundwater-flow zones - one shallow and the other deep-overlie the bedrock at the reservoir. Water level data were analyzed from 38 slug tests to determine the hydraulic conductivity of the sediments surrounding the well-screen zones. Hydraulic conductivity values at the reservoir ranged from 0.0012 to $2 \mathrm{ft} / \mathrm{d}$, with the lowest and highest values at wells TB-3D and MR-100PA, respectively. The hydraulic conductivity of the shallow waterbearing unit ranged from 0.0026 to $1 \mathrm{ft} / \mathrm{d}$, with the lowest and highest values at wells TB-17S and TB-4S, respectively; and the hydraulic conductivity in the deep saturated zone on the southern embankment ranged from 0.0012 to $2 \mathrm{ft} / \mathrm{d}$, with the lowest and highest values at wells TB-3D and MR-100PA, respectively. Hydraulic conductivity at the toe of the earthen dam ranged from 0.016 to $0.27 \mathrm{ft} / \mathrm{d}$, with the lowest and highest values at wells TB-13 and TB-15, respectively.

Slug test results indicate that the deep saturated zone on the southern embankment of the Hillview Reservoir has a relatively higher permeability and a greater capacity to transmit water than the shallow saturated zone above it. Of the 31 tested wells on the southern embankment, 6 of the 7 wells with the highest hydraulic conductivities are screened in the deep saturated zone on the western side of the southern embankment in proximity to the south connecting conduit.

\section{References Cited}

Asselstine, E.S., and Grossman, I.G., 1955, The ground-water resources of Westchester County, New York, Part 1, Records of wells and test holes: New York State Water Power and Control Commission Bulletin GW-35, 79 p., 3 pls.
Baskerville, C.A., 1982, Adoption of the name Hutchinson River Group and its subdivisions in Bronx and Westchester Counties, southeastern New York, in Stratigraphic notes, 1980-1982: U.S. Geological Survey Bulletin 1529-H, p. $\mathrm{H} 1-\mathrm{H} 10$.

Baskerville, C.A., 1992, Bedrock and engineering geologic maps of Bronx County and parts of New York and Queens Counties, New York: U.S. Geological Survey Miscellaneous Investigations Series, map I-2003, 2 sheets, scale 1:24,000.

Board of Water Supply of the City of New York, 1909, Hillview Reservoir: New York City Department of Environmental Protection Board of Water Supply of the City of New York Contract 30, [n.p.].

Board of Water Supply of the City of New York, 1929, Hillview Reservoir: New York City Department of Environmental Protection Board of Water Supply of the City of New York Contract 224, [n.p.].

Bouwer, H., and Rice, R.C., 1976, A slug test for determining hydraulic conductivity of unconfined aquifers with completely or partially penetrating wells: Water Resources Research, v. 12, no. 3, p. 423-428.

Bouwer, H., 1989, The Bouwer and Rice slug test - an update, Ground Water, vol. 27, no. 3, pp. 304-309.

Capurso, W.D., Chu, J.J., Chu, S.A., and Noll, M.L., 2019, Data and analytical type-curve match for selected hydraulic test in New York State: U.S. Geological Survey data release, https://doi.org/10.5066/P9J404KW.

Chu, A., Stumm, F., Joesten, P.K., and Noll, M.L., 2013, Geophysical and hydrologic analysis of an earthen dam site in southern Westchester County, New York: U.S. Geological Survey Scientific Investigations Report 2012-5247, 64 p. (Also available at https://doi.org/10.3133/sir20125247.)

Cunningham, W.L., and Schalk, C.W., 2011, Groundwater technical procedures of the U.S. Geological Survey: U.S. Geological Survey Techniques and Methods, book 1, chap. A1, 162 p. [Also available at https://doi.org/10.3133/ tm1a1.]

Duffield, G.M., 2007, AQTESOLV for Windows version 4.5 user's guide: Reston, Va., HydroSOLVE, Inc., 529 p.

Freeze, R.A., and Cherry, J.A., 1979, Groundwater: Englewood Cliffs, N.J., Prentice Hall, 604 p.

In-Situ Inc., 2015, Level TROLL 500 data logger: In-Situ Inc. website, accessed June 16, 2015, at https://in-situ.com/ products/level-temp-data-loggers/level-troll-500-datalogger/. 
Malcolm Pirnie, Inc., and TAMS Consultants, Inc., 2002,

Capital project $\mathrm{W}-10$, Hillview reservoir - Cover, phase I, dividing wall stability buttress construction; south embankment monitoring and leakage investigations: U.S. Environmental Protection Agency, 18 p.

Noll, M.L., and Chu, A., 2018, Groundwater-level data from an earthen dam site in southern Westchester County, New York: U.S. Geological Survey Data Series 1075, 35 p., accessed November 2, 2018, at https://doi.org/10.3133/ ds 1075. 
For more information, contact

Director, New York Water Science Center U.S. Geological Survey

2045 Route 112, Building 4

Coram, NY 11727

dc_ny@usgs.gov

https://ny.water.usgs.gov/

Publishing support provided by the Pembroke Publishing Service Center 
